\title{
NOTE
}

\section{A new sediment trap system}

\author{
Ulf Larsson ${ }^{1,2}$, Sven Blomqvist ${ }^{1,3} \&$ Berndt Abrahamsson ${ }^{1}$ \\ ${ }^{1}$ Askö Laboratory, ${ }^{2}$ Department of Zoology, ${ }^{3}$ Department of Geology, University of Stockholm, S-106 91 Stockholm, Sweden
}

\begin{abstract}
A new sediment trap system intended for use in lakes and marine coastal and shelf areas is presented. The system is designed to (1) keep the sediment collection tubes in a steady vertical position, (2) avoid contamination of the samples by material detached from overhead rigging, (3) facilitate quick exchange of collection tubes at sea, and (4) provide duplicate samples. In situ experimental studies, SCUBA diving observations, and several years of field use support the reliability of the sediment trap system developed.
\end{abstract}

The rationale for using sediment trap techniques to assess downward settling fluxes of particulate matter in aquatic environments has been strengthened considerably in recent years (cf. reviews by Gardner 1977 , Bloesch \& Burns 1980, Reynolds et al. 1980, Blomqvist \& Håkanson 1981). Several studies have defined certain criteria that a sediment trap must meet in order to minimize bias in estimates of sedimentation rates. The sediment trap should have (1) a cylindrical collection vessel (tube) (Gardner 1977, 1980a, b, Hargrave \& Burns 1979) with (2) an inner tube diameter of $\geqslant$ $45 \mathrm{~mm}$ (Blomqvist \& Kofoed 1981) and (3) an aspect ratio (height: diameter, $\mathrm{H}: \mathrm{D}$ ) of 3 to 5 (Wahlgren \& Nelson 1977, Blomqvist \& Kofoed 1981, Saure 1981) or higher in horizontal water currents over $10 \mathrm{~cm} \mathrm{~s}^{-1}$ (Bloesch \& Burns 1980). It is crucial that the collection tube maintains a steady vertical position, irrespective of water currents, internal waves, and pulling, strumming and slanting of mooring lines (cf. Gardner 1980a, 1985, Blomqvist \& Håkanson 1981). However, published descriptions of buoy-supported, moored sediment traps (e.g. Knauer et al. 1979, Larrance et al. 1979, Jannasch et al. 1980, Landing \& Feely 1981, Lorenzen et al. 1981, Rathke et al. 1981, Sasaki \& Nishizawa 1981, Gulliksen 1982, Baker \& Milburn 1983, Gardner et al. 1983, Håkanson 1984, see also review by Blomqvist \& Håkanson 1981) suggest to us that they are unlikely to maintain a proper vertical position under normal field conditions.
We present here a new sediment trap system for use in lakes and marine coastal and shelf areas, designed to meet these demands. The system includes an anchoring arrangement which permits mooring without suspension lines above or close to the self-buoyant sediment trap.

Construction of the sediment trap. The trap (Fig. 1) consists of a sealed hollow frame, a cylindrical buoyant body (volume $7.5 \mathrm{l}$, weight $1 \mathrm{~kg}$ ), and 2 gimbalmounted collection tube holders stabilized with $2.4 \mathrm{~kg}$ of concrete at the lower end. Settling particulate matter is collected in easily exchangeable inset collection tubes, with inner and outer diameters of 105 and $110 \mathrm{~mm}$, respectively, and a height of $500 \mathrm{~mm}(\mathrm{H}: \mathrm{D}$ ratio of 4.8). The collection tubes project from their holders by $10 \mathrm{~cm}$, allowing quick and easy exchange of the tubes from a small boat as the sediment trap floats on the water surface.

The frame, clasps, tube holders and gimbal suspensions are made of grey polyvinyl chloride (PVC), the collection tubes from transparent PVC, and the axes of the gimbal suspension of brass. The attachment swivel beneath the trap is stainless steel and the buoyant body is closed-cell foamed PVC.

Deployment. The positive buoyancy of the new sediment trap permits the use of a 2-anchor mooring arrangement, which minimizes the risk of attached fouling growth and flotsam on lines and buoys detaching and falling into the trap (Fig. 1). The deployment depth of the trap is adjusted by the length of the trap retaining line to Anchor I. Upon deployment, Anchor I is first lowered by the ground line connecting Anchor I and II. At a certain depth Anchor I will submerge the floating sediment trap. When Anchor I rests on the bottom, Anchor II is positioned by the surface line while the boat is moving away. Retrieval is carried out in the reverse order. This anchor mooring arrangement is convenient in relatively shallow areas such as lakes, 


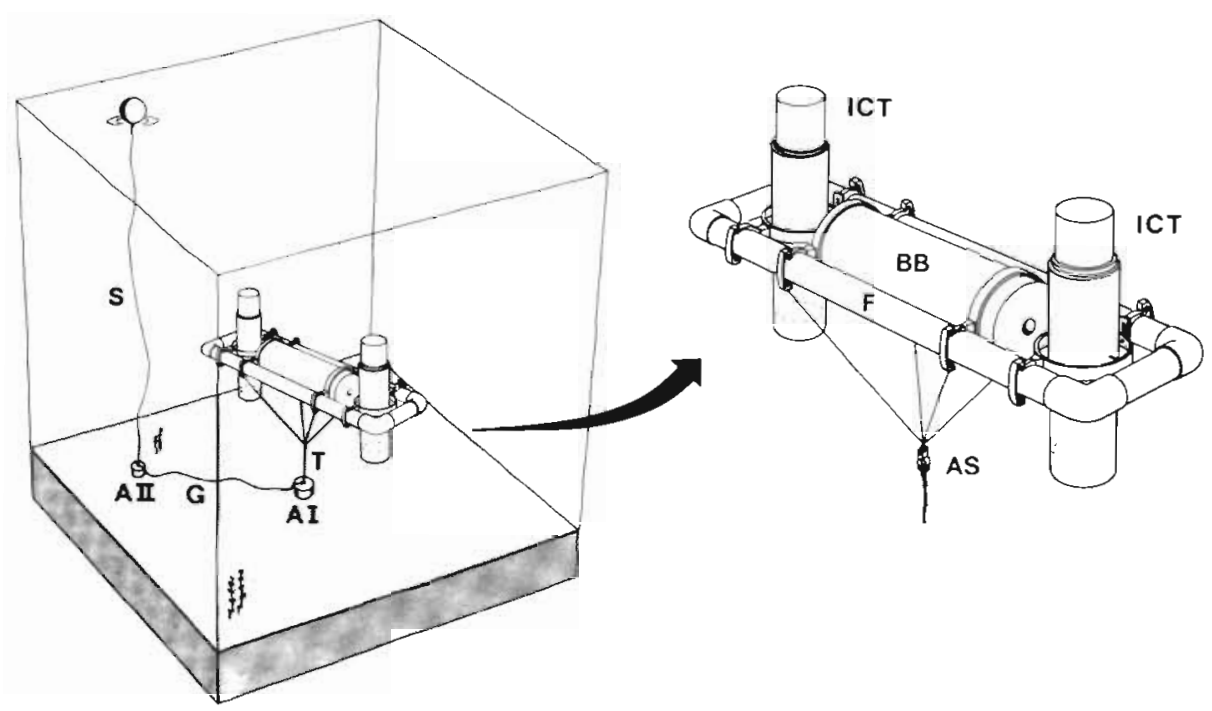

Fig. 1. The self-buoyant sediment trap with 2-anchor mooring arrangement. AI, AII: Anchors I and II, respectively; T: trap retaining line; $G$ : ground line; $S$ : surface line. Line $T$ is always taut whereas $G$ and $S$ are usually slack. ICT: inset collection tube BB: buoyant body; F: frame; AS: attachment swivel. Dimensions of hollow frame: outer length $110 \mathrm{~cm}$, outer width $30 \mathrm{~cm}$, outer diameter of the tubes $5 \mathrm{~cm}$, wall thickness $0.4 \mathrm{~cm}$

and marine coastal and shelf areas. Similar mooring arrangements are used to deploy current sensors (cf. Duxbury 1971).

Study location and field test. The new sediment trap was tested in the Baltic Sea, near the Askö Laboratory about $65 \mathrm{~km}$ south of Stockholm, Sweden, in an archipelago area with negligible tide. The main test was carried out at $1.5 \mathrm{~m}$ depth in a narrow, $3.5 \mathrm{~m}$ deep sound, with relatively turbulent currents of up to $40 \mathrm{~cm}$ $\mathrm{s}^{-1}$. The degree of vertical stability of the collection tubes was recorded in situ by time-lapse filming.

An $8 \mathrm{~mm}$ film camera was enclosed in a waterproof housing and mounted at the bottom of one of the collection tubes; the other tube was counterbalanced with gravel. The inner diameter of the tubes had to be $150 \mathrm{~mm}$, to allow space for the camera. The entire trap was therefore scaled up according to the difference between the tubes in this test trap and the regular trap described above. At the top of the camera tube, 2 independent protractors were mounted, and readings recorded on film every $30 \mathrm{~s}$. One protractor acted as a pendulum, recording the deviation from the vertical of the tube, the other was connected to an outside arm in order to give a relative reading of the current velocity. To relate the relative readings to actual current velocities a current meter was deployed close to the trap, integrating current velocities over $10 \mathrm{~s}$. Readings were taken at intervals of 1 to $5 \mathrm{~min}$. These current measurements were correlated to the corresponding protractor readings recorded on the film, using non-linear regression by SAS software (Allen Rey 1982). The regression equation (protractor reading $=0.203$ current velocity ${ }^{1.499}, \mathrm{n}=26$ ) was then used to estimate water currents every $30 \mathrm{~s}$.

Results. Despite highly variable water currents (5 to $40 \mathrm{~cm} \mathrm{~s}^{-1}$ ) the collection tube of the new sediment trap

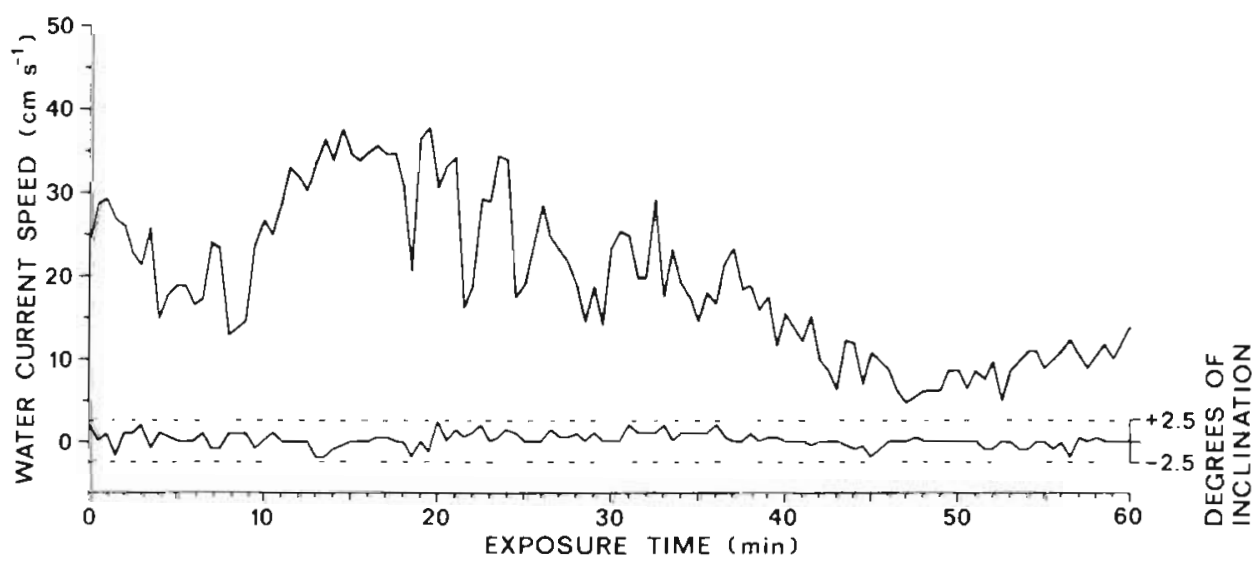

Fig. 2. Predicted ambient water current velocities (above) and simultaneous recording, by time-lapse filming in situ, of the inclination from vertical of the collection tube of the sediment trap (below) 
never deviated more than $\pm 2.5^{\circ}$ from a true vertical position (Fig. 2). Observations by water glass confirmed that the trap does not wobble and invariably maintains an alignment perpendicular to the current direction. In situ inspections of the regular trap by SCUBA diving at water depths down to $12 \mathrm{~m}$ in a coastal area support these observations. Not even when the diver rocked the trap frame did the collection tubes deviate noticeably from the vertical.

Concluding remarks. The new sediment trap maintains satisfactory stability of the collection tubes and an alignment perpendicular to the current direction at highly variable current velocities (up to at least $40 \mathrm{~cm} \mathrm{~s}^{-1}$ ). The buoyancy of the trap permits a noninterfering mooring arrangement. The new trap has functioned reliably for more than $4 \mathrm{yr}$ in a coastal area of the Baltic Sea.

Acknowledgements. Ragnar Elmgren and Jürg Bloesch commented on the manuscript, Sture Hansson assisted in the diving, Leif Lundgren drew the figures and Maureen Moir typed and corrected the language. This work was supported by the National Swedish Environment Protection Board and the Swedish Natural Science Research Council.

\section{LITERATURE CITED}

Allen Rey, A. (ed.) (1982). SAS user's guide: Basics. SAS Inst. Inc., Cary, North Carolina

Baker, E. T., Milbum, H. B. (1983). An instrument system for the investigation of particle fluxes. Cont. Shelf Res. 1: $425-435$

Bloesch, J., Burns, N. M. (1980). A critical review of sedimentation trap technique. Schweiz. Z. Hydrol. 42: 15-55

Blomqvist, S., Hăkanson, L. (1981). A review on sediment traps in aquatic environments. Arch. Hydrobiol. 91: 101-132

Blomqvist, S., Kofoed, C. (1981). Sediment trapping - a subaquatic in situ experiment. Limnol. Oceanogr. 26: 585-590

Duxbury, A. C. (1971). The earth and its oceans, Chap. 18. Addison-Wesley Publishing Company, Reading, Massachusetts

Gardner, W D. (1977). Fluxes, dynamics, and chemistry of particulates in the ocean. Ph.D. thesis, Mass. Inst. Technol./Woods Hole Oceanogr. Inst., Massachusetts

Gardner, W. D. (1980a). Sediment trap dynamics and calibration: a laboratory evaluation. J. mar. Res. 38: 17-39
Gardner, W. D. (1980b). Field assessment of sediment traps. J. mar. Res. 38: 41-52

Gardner, W. D. (1985). The effect of tilt on sediment trap efficiency. Deep Sea Res. 32A: 349-361

Gardner, W. D., Richardson, M. J., Hinga, K. R., Biscaye, P. E. (1983). Resuspension measured with sediment traps in a high-energy environment. Earth Planet. Sci. Lett. 66: $262-278$

Gulliksen, B. (1982). Sedimentation close to a near vertical rocky wall in Balsfjorden, northern Norway. Sarsia 67: $21-27$

Håkanson, L. (1984). Suspension and calibration of a sediment trap. Schweiz. Z. Hydrol. 46: 171-175

Hargrave, B. T., Burns, N. M. (1979). Assessment of sediment trap collection efficiency. Limnol. Oceanogr. 24: $1124-1136$

Jannasch, H. W., Zafiriou, O. C., Farrington, J. W. (1980). A sequencing sediment trap for time-series studies of fragile particles. Limnol. Oceanogr. 25: 939-943

Knauer, G. A., Martin, J. H., Bruland, K. W. (1979). Fluxes of particulate carbon, nitrogen, and phosphorus in the upper water column of the northeast Pacific. Deep Sea Res. 26A: $97-108$

Landing, W. M., Feely, R. A. (1981). The chemistry and vertical flux of particles in the northeastern Gulf of Alaska. Deep Sea Res. 28A: 19-37

Larrance, J. D., Chester, A. J., Milburn, H. B. (1979). A new sediment trap and particulate flux measurements in lower Cook Inlet, Alaska. Mar. Sci. Communs 5: 269-282

Lorenzen, C. J., Shuman, F. R., Bennett, J. T. (1981). In situ calibration of a sediment trap. Limnol. Oceanogr. 26: 580-585

Rathke, D. E., Bloesch, J., Burns, N. M., Rosa, F. (1981). Settling fluxes in Lake Erie (Canada) measured by traps and settling chambers. Verh. Int. Verein. Limnol. 21: $383-388$

Reynolds, C. S., Wiseman, S. W., Gardner, W. D. (1980). An annotated bibliography of aquatic sediment traps and trapping methods. Occas. Publ. No. 11, Freshwat. Biol. Assoc., Ambleside

Sasaki, H., Nishizawa, S. (1981). Vertical flux profiles of particulate material in the sea off Sanriku. Mar. Ecol. Prog. Ser. 6: 191-201

Saure, A. (1981). Die Zufuhr von organischer Substanz zum Sediment und ihre Bedeutung für das Ókosystem Kieler Bucht. Diplomarbeit, Inst. Meereskunde, Univ. of Kiel

Wahlgren, M. A., Nelson, D. M. (1977). Factors affecting the collection efficiency of sediment traps in Lake Michigan. Argonne National Laboratory, Radiol. Environ. Res. Div. Ann. Rep., ANL-76-88 Part III: 103-106, Argonne, Illinois

Accepted for printing on April 4, 1986 